\title{
The EU polycrisis and hard populism in East-Central Europe: From the Copenhagen dilemma to the Juncker paradox
}

\author{
ATTILA ÁGH
}

$\frac{\text { DE }}{\mathrm{G}} \stackrel{\text { DE GRUYTER }}{\text { OPEN }}$

Politics in Central Europe (ISSN: 1801-3422)

Vol. 13, No. $2 / 3$

DOI: $10.1515 /$ pce-2017-0001

\begin{abstract}
Analyses of populism in East-Central Europe (ECE) necessarily depart from the general crisis of representative democracy in the EU and describe the ECE as a specific regional case reflecting the failure of the catch-up process. The first part of this article adopts this "classical" approach and considers the backsliding of ECE democracy alongside the rise of populist identity politics in the global context. In the second part, I turn to the historical trajectory of ECE populism as a "nested" or two-level game in the EU context of ECE developments. The third part of this article outlines the main contradictions in this process that has led to what I call the Juncker paradox. To understand this paradox, we need to return to what the Commission noted in the early 2010s as the Copenhagen dilemma: after the EU accession of ECE states, the EU had no means to control rule-of-law violations and, in fact, supported autocratic populist ECE regimes through European transfers. This article explains the worsening of this situation in the late 2010s as the EU polycrisis caused Juncker's Commission to focus on Core-based priorities and marginalise rule-of-law violations in ECE. This inaction and neglect have produced a special case of negative externalities - the Juncker paradoxthat has largely been counterproductive and further strengthened anti-EU populism in all ECE countries, especially Hungary and Poland. Despite this situation, I conclude that Juncker's 2017 State of the Union address should be a turning point in the EU's policy towards ECE; in particular, it should promote a better understanding of the regional situation and more effective enforcement of the rule of law.
\end{abstract}

Key words: East-Central Europe, polycrisis, EU 


\section{Rethinking the "classical" approach: The contamination of identity politics in ECE}

In the last quarter century, an empty representative democracy has emerged in East-Central Europe with democracy reduced to mere electoral democracy as populations grow alienated from elected parties and politicians, a trend evidenced in the reports of major reviewers (BF 2016, 2017; FH 2017; WEF 2017a, b, c). Initially this situation led to the soft populism of the first party system and later - after critical elections - to the hard populism of the second party system (see, e.g., Haughton - Degan-Krause 2015; Havlik - Voda 2016). Soft populism had a basically domestic orientation, focusing on "internal enemies" while hard populism has found its main enemy in the EU, a target that leads me to call it "Eupopulism". This article deals first with the decline of representative democracy in EU states, a process I consider mostly from the point of view of ECE domestic developments. I then analyse the EU context as a nested game, taking into account both the neglect of the new member states during the EU's management of the global crisis and the re-nationalisation of politics in ECE where abuse of the "Brussels demon" has helped consolidate populist regimes. While the rollback of Europeanisation and decline of democracy have mostly been domestically induced processes in ECE, the EU's negative externalities have also played an important role. EU membership has meant a demand for compliance with EU rules and values, however the EU has not elaborated any enforcement mechanism to deal with non-compliance in ECE. The lack of proper mechanisms to address the systemic failures of Europeanisation and democratisation has largely encouraged populist regimes. ${ }^{1}$

More generally, identity politics has swept across the world since the global crisis, making itself felt primarily in the most developed countries but also having a powerful contaminating effect in ECE. Since the mid-2010s, the erosion of European identity - reinforced by the Brexit decision and the US election of Donald Trump - has emerged as one of the most fashionable topics in European Studies (Engesser - Fawzi - Larsson 2017). While the Euro-crisis has to some extent been overcome economically, it has deepened into a social and even more clearly a "cultural" and "national" identity crisis. As populist parties grow stronger, identity politics has been the main driver of collective action for marginalised populations. The conditions behind this "new" wave of populism have only been worsened by the current geopolitical crisis. In look-

1 I have dealt with the current eruption of populism in other recent publications (Ágh 2016a-d). This article offers only an outline of the socio-economic and cultural deficits and the distinction between external and internal Europeanisation that I have discussed in previous articles. My focus here is on the historical trajectory of Eupopulism, and thus, I broadly describe Hungarian developments with some reference to Poland. Although there are striking similarities across the new member states in the new populist wave, I concentrate here on the ECE countries. 
ing for reasons for the sudden rise of populism in the EU, we may note two preparatory processes: the socio-economic crisis and growing inequality and "societal frustration" (Klipcerova-Baker - Kostál 2017) on the one hand, and an underlying cultural-political crisis leading to the erosion and re-nationalisation of European identity on the other. These two processes in the EU have been accelerated and reinforced at a political level by Brexit as a direct concern for the EU28 as well as by Trump's election.

The sudden turn to identity politics has primarily been facilitated by the global cultural processes of the information age. We have, thus, seen a seeming eruption of populism in a very short time via global information networks. The global rise of populism (Moffitt 2016) can be attributed to new media technologies since media now pervades political life; this is also why the new populism has spread so rapidly around the world. Emerging from its earlier iterations to convey the new message of identity politics, populism has increasingly been embedded in a fast-shifting media communications landscape. What is novel here is the reliance on new media technologies and on shifting modes of political representation and identification across a great variety of political and cultural contexts. In a recent book, Moffitt (2016) attempts to locate populism within the global media landscape in an era of "communicative abundance", noting the increasing affordability of communication technologies and the widening scope and growing speed of communication and information networks. In this new age of increased mediatisation, ECE populist leaders have also learned to use new media technologies to their advantage. Moffitt's account, thus, offers a global media-centred understanding of contemporary populism that focuses on changing media and the mediatisation of politics. In this context, politics is increasingly being reshaped and altered as the influence of globalised media grows. ${ }^{2}$

The populist eruption has also meant an eruption of identity politics for the various groups who are looking for points of identification and representation through the still unmastered and rather chaotic digital communication of this media Babel. Identity politics is not new to the recent populism, and the history of the EU has always been attended by debates on European identity. This issue has been discussed in relation to EU citizenship and the EU's popular legitimacy as well as in relation to the different levels of local, national and regional identity. The new approach distinguishes between two conceptually separate components of identity: the civic and the cultural. The civic pillar reflects a citizen's identification with a political system and the rights and du-

2 In addressing cultural globalisation, Moffitt claims to move beyond purely regional approaches to populism, which he describes as a form of "academic ghettoization". Nevertheless, the specific regional forms of populism demand study since these regional waves and varieties of populism are very different. Moffitt's own work demonstrates that even in this era of mediatised global populism, there is some divergence in the "mega-regional" varieties of populism, most critically between Europe and the United States. 
ties it confers on him/her as a political being. In contrast, the cultural pillar speaks to the citizen's sense of belonging to a human community where there is a common culture, social similarities and values or even a common ethnicity (Bruter 2008: 279). Merler (2017a, b) has recently summarised the debate on the relations between European identity and the protracted economic crisis by pointing out the tensions between pan-European elite identity (Eurocracy) and a deeper sense of common citizenship across the EU. She warns that civic identity has been eroded during the economic crisis and notes that recovery has been described as the "[r]ebuilding [of] economic and political capital for EU integration" (2017a, b) since legal fetishism has done serious damage to European identity. (For more on these themes, see below.)

This split between elite and citizen types of EU identity has disrupted the previous Europeanisation of national identities into "dual" (national and EU) components to such an extent that some analysts have condemned the "post-national dream" of European identity (Duchesne 2014).To begin with, the current EU identity crisis has challenged the global status of the EU. Second, it has highlighted the divorce between the technocratic and democratic EU, and third, it has compounded the tensions between so-called Core and Periphery identities. Moreover, in the countries most seriously hit by the global crisis, national identities have been reinforced while EU identifications have declined dramatically. The debate is ongoing given the apparent eruption in the 2010s of a wide variety of identities both globally and regionally, including in ECE. In sum, identity politics has played a central role in the new wave of populism, and this is contrasted with growing emptiness of representative democracy. As Ehala (2017) observes: "In the contemporary world, we are obsessed with identity. [...] Thus, identity issues have become contentious in the modern world, yet our understanding of identity is a mess" (p. 1). ${ }^{3}$

Identity politics has turned out to be the flagship for populist politics on both the left and the right as well as for all kinds of ethnicities and cultural groups. It has, moreover, been discussed and analysed by politicians, citizens and experts across several disciplines. This situation has been a great push for social constructivist approaches in the social sciences since collective identities are social constructed (Ehala 2017: 3-9). What Ehala calls the "sign system of collective identities" changes as civilisation evolves and explosive advances of information technology radically alter communication. At the same time, we find that as a major ideology shaping inter-group relations, "liberal" multicul-

3 The European identity crisis first came to a head in the mid-2000s after the failure of the European Constitution, resulting in a large body of literature on this topic. In particular, the Journal of Contemporary European Studies published a special issue in 2008 featuring a lead paper by Bruter. My own book, Eastern Enlargement and the Future of the EU27 (Budapest: Together for Europe Foundation, 2006, 237-288) includes a chapter devoted to the "identity crisis in the enlarged EU" which discusses both "cultural politics" and "civic democracy" from the standpoint of soft populism. 
turalism now reveals an internal conceptual paradox since the eruption of a wide array of ever-changing identities has challenged the "liberal" system itself. This is clear both from newly emerging intolerant minority ideologies and from the challenged cultural majority that is behind nascent hard forms of populism. Furthermore, the eruption of collective identities from all directions has led to the erosion of social capital even in developed and consolidated democracies.

Against this backdrop of recent conceptual turmoil in discussions of the new populism and its identity politics, Buti and Pichelmann (2017) attempt to provide a systemic overview of what they call European integration and populism. Their analysis begins with a strong charge: EU institutions and policy settings are prone to populist attacks from both a purely economic and more cultural "nativist identity" angle since these institutions neglect the real problems of the EU population. Current competencies, mostly confined to the organising of markets and not extending to the question of distribution effects, make the EU appear like an agent of globalisation within Europe rather than the means for a joint European response to globalisation. Buti and Pichelmann (2017) focus on the increasing tension between proponents of globalisation and the populations of EU member states that has resulted in a rising tide of nationalistic and, in fact, often nativist, go-it-alone policy approaches. The EU has, thus, been charged with undermining national autonomy, identity and control.

For Buti and Pichelmann, it appears that while the EU integration process has been the bedrock for peace and economic development for half a century, it can no longer be taken for granted. In particular, they note that the EU integration process has traditionally been conceived as a means to square the circle, allowing for the catching up with economic growth and convergence while preserving Europe's social model as reflected in the EU social acquis. The financial crisis has, however, only fuelled an already existing undercurrent of discontent and fading trust in democratic institutions and in the willingness of elites to deal with the (real or imagined) unfair distribution of benefits and burdens in society. In this context, EU institutional settings and policies are increasingly being perceived as having a pro-market bias and paying little (if any) attention to their social impact that has undermined cohesion, solidarity, autonomy and governability at the national, regional and local levels. The backlash against globalisation and EU integration, thus, runs deeper than cheap populism since it has economic and cultural roots that should not be dismissed too easily.

The losers in the globalisation process have become highly visible while the middle classes have seen scant evidence of once promised gains. Whether or not globalisation is the main culprit, it does not take a populist to notice that the last few decades have seen the top $1 \%$ grab an ever-growing share of the national income and wealth while median incomes have stagnated. It has to be acknowledged that some attacks from populists respond to real grievances; moreover, not everyone who criticises the ruling elites is a populist. What is 
striking, however, about populism is the rhetoric that it draws on: amidst multiple insecurities that threaten the social fabric, populists invoke the dichotomies of "real people" versus "the establishment" and honest (native) ordinary people versus corrupt elites. They also claim to represent the true will of the people and to express common sense instead of manipulated expert opinions. Their standard repertoire, thus, includes ridiculing expert opinions (a task that is admittedly sometimes all too easy) and denouncing statistical evidence as abstract and out of line with the experiences of ordinary people. Populists have also been quick to realise the potential of social media given their (partly real, partly imaginary) claims to create a space for common identity and to establish direct links between citizens and their true representatives who speak the will of the no-longer-silent majority. In this context, Buti and Pichelmann (2017) note that cultural globalisation and identity politics have afforded populist regimes a kind of soft power; they have only needed to insert an enemy image as content.

Significantly, the EU has been highly vulnerable to populism since the long period of representative democracy was dominated by a legal or formalistic approach to EU democracy. The recent populist wave has only confirmed that the "capacity for electoral institutions to affect attitudes about representative democracy may be more limited than previously appreciated" (Donovan - Karp 2017: 469). Legal formalities matter even less in ECE while political corruption and social inequality are more substantive issues. When asked "what they expected from democracy as a general concept, and what they thought democracy actually delivered in their own country" (Donovan - Karp 2017: 471) - a distinction usually analysed in David Easton's terms of diffuse versus specific support for democracy - people in ECE reported a much bigger gap or contrast between the two categories than those in the old member states. Similarly, in one of the most recent populism studies, Agerberg (2017: 581) emphasises that the good government and democratic behaviour of elites have substantial impact on people's specific support for the political system. He also notes that high rates of corruption have greatly contributed to the populist wave in ECE and drastically diminished any specific support for democracy.

Looking more closely at the ECE, it is clear that after a period of soft populism characterised by attacks on the "old" and "postcommunist" impotent domestic elite, the new hard populist regimes have found an enemy in the EU. In this vein, they have used "Brussels" as a bugaboo for the consolidation of autocratic regimes. To make matters worse, ECE governments have produced a series of placebo reforms that claimed to target increasing inequality after the global crisis; the failure of these reforms has only reinforced the populist drive. This manipulation of the placebo effect is most striking among those ECE populist parties whose empty promises in the media have created the appearance of functioning democratic institutions and practices; in this way, they suggest that their government would have acted to save the poorest in society from the 
dire effects of the crisis. This crisis of representative democracy may be hard to overcome in ECE since no strategic steps have been taken to end the division of society into winners and losers, and indeed, even some winners are threatened by these precarious conditions. Instead, ECE populist movements have offered the false medicine of identity politics, which has become a key feature of representative democracy in crisis.

\section{The "nested game" approach: The historical trajectory of ECE Eupopulism}

Although domestic socio-economic and political processes bear most of the blame for the apparent surge of populism in ECE, the EU's neglect and inaction around ECE crisis management have also contributed significantly to the emergence of hard populism. During the 2010s, the EU has given growing manoeuvring room to incoming populist elites to grab power and consolidate hard populism through second party systems after critical elections. This nested game, or two-level process, and its close relationship with the emergence of hard populism is not usually discussed in European Studies since the EU's negative externalities generally remain a forgotten dimension of Core-Periphery relations. In fact, the Core-Periphery divide since the global crisis has split the EU more deeply than ever before and produced a specific Eupopulism in the "East".

This situation demands a radical re-conceptualisation since new analytical devices are needed to theorise these new conflicts between the Core and the Periphery. I would suggest that a three-step analysis of the nested game can shed some light on the divergence of ECE states from mainstream EU developments. This analysis might proceed as follows: (1) The point of departure is the total "civilisational" (socio-economic and cultural) deficit of the ECE states before accession and their emerging relative deficit after accession; this deficit in civic political culture produced weak informal institutions; (2) The result has been a gap between the ECE states' external, formal-legal Europeanisation and their internal, substantive-cultural Europeanisation during their membership; this deficit has led to "formal" rather than "effective" membership, that is, to the construction of legal scenery that still has no socio-economic content behind it and to steadily increasing socio-political polarisation; (3) The endgame has been the emergence of hard populism with relative de-Europeanisation and de-democratisation in the EU. Cumulative societal frustration and a new cultural deficit have, thus, ruined emerging participatory and sustainable democracies, and this has led to socio-economic and political deconsolidation. ${ }^{4}$

4 In this vein, we should also distinguish between absolute and relative socio-economic exclusion. Absolute exclusion refers to the situation of the millions who lost jobs that were pegged to an older age of industrialisation and were never reintegrated into society. In contrast, relative exclusion describes those 
In contrast, from the EU's standpoint, this historical trajectory might unfold as follows: (1) At the start of the accession process, the EU did not respond to ECE's historical deficit and, thus, did not create a road map to deal with the historical and new relative deficits emerging from the new institutional and cultural demands of membership (see my remarks on the Copenhagen dilemma below); (2) The EU accepted superficial, formal-legal transformations as valid Europeanisation and democratisation and hoped for a "trickle-down" effect despite all increasingly dramatic evidence to the contrary (see my remarks on the excuse of differentiated integration below); (3) The Core underestimated emerging ECE hard populism, which it took to be a transitory political deviation despite the deepening socio-economic crisis (see my remarks on "light touch" legal mechanisms below). All in all, then, it seems clear that neglect and an absence of empathy have proven highly counterproductive for Core-Periphery relations in the 2010s.

It must be reiterated that European Studies has ignored the distinction between absolute (historical) and relative (EU-related) deficits. On this count, it is important to note that after World War II, the ECE states were excluded from Western developments and they entered a new, unknown socio-political universe upon their EU membership. At the start of democratisation, the ECE countries, thus, had a much lower level of economic development than their Western counterparts as well as a serious institutional and cultural deficit. I call this historical legacy the "absolute" deficit and note that it was increased significantly by accession given the "relative" deficit created by the new, very complex requirements of EU membership. Sztompka (2000) argues justifiably that the accession process generated dual effects of "triumph and trauma" and this has produced a socio-cultural deficit. Although on the one hand ECE populations experienced triumph in their so-called return to Europe, on the other, they worried about their lack of competitiveness in the midst of globalisation. This cumulative absolute and relative deficit has dictated ECE's trajectory in recent decades to a great extent. Moreover, over the last quarter of a century, this deficit has not disappeared but, on the contrary, only grown in many respects. ${ }^{5}$

This situation is particularly clear from the treatment of the refugee crisis. Lehne (2016) writes that the "European response to the refugee crisis has been rooted in deep-seated structural factors" (p.?), an observation that rings particularly true for ECE. The negative stance taken by ECE countries on the refugee

who have been marginalised for failing to meet the new socio-economic requirements. This situation has destroyed the myth of the emerging middle class.

5 As the title of Ivan Krastev's (2016) article "Liberalism's Failure to Deliver" indicates, the "liberal order" has not delivered what it promised to EU populations. For more on this theme, see Dawson and Hanley (2016) and, more generally, the October 2016 and January 2017 special issues of Journal of Democracy on ECE populism. For more specific analyses, see Rupnik (2016), Bugaric and Ginsburg (2016) and Fomina and Kucharczyk (2017) on the "new spectre" haunting ECE. 
situation can be traced not only to elitist politics, but to a prevailing mindset; the increasingly negative mood of these states is anchored both in their heritage and in the experience of the socio-economic crisis among the vast majority of ECE populations. Lehne (2016) observes that "[e]ven more negative were the reactions in Central European member states, which had lived in relative isolation for decades and whole societies were unprepared for large influxes of foreigners" (p. 3). Against this backdrop, the EU has produced what might be called a crisis of crisis management, having failed to realise the meaning of the refugee crisis for the EU population as a whole and for ECE populations particularly with their specific historical experience over centuries and their unpreparedness for non-European migration. For these reasons and because of the EU's neglect of ECE's particular situation, the refugee crisis has pushed ECE populations into the worst kind of native-identity politics. Through its counterproductive approach, the EU has, thus, contributed to the re-nationalisation of ECE politics and the consolidation of hard populism.

As for the divergence between external and internal Europeanisation, it must be noted that large Western constitutional institutions were transferred to ECE in the absence of their socio-cultural environments, that is, without the proper social embeddedness and informal underpinnings that make formal institutions work. Furthermore, this socio-economic and cultural environment has not been developed during the membership period. As we have seen, the EU did not provide ECE states with a road map as a catch-up strategy when they entered this unchartered territory. Rather, as Scharpf (2015) points out, the Union's main strategy was a very general plan of formal "judicial integration" that actually amounted to "bypass[ing] [...] integration through law" (p. 386). All this took place without any regard for the socio-economic preconditions or socio-political outcomes of legislative activity. Instead, the EU was treated as a homogeneous social and cultural space for the application of any kind of legislation.

Given this background, Scharpf (2015) has, in fact, proposed a new approach to explain the EU "polycrisis"; it is, he writes, the cumulative effect of this process of integration through law:

Governments have failed to appreciate the coup d'état of the European Court of Justice (ECJ), which in 1963 and 1964 had postulated the supremacy and direct effect of European law. As a consequence, 'integration through law' became an option to bypass political legislation through 'judicial legislation' if agreement in the Council could not be obtained.

Furthermore, Scharpf (2015) notes that even in times of crisis, "bypass[ing] integration through law has been effective" and serious conflicts have been "resolved through judicial action" despite a lack of economic and political feasibility (p. 396). This long-term EU strategy - moving forward via judicial action while neglecting reality and lacking proper economic, political and social integration - has amounted to pseudo-conflict resolution and only added to the 
tensions. As such, it has heightened the opposition of the EU population as a whole to technocratic-professional elites with their regular victory reports. At the same time, it has compounded the sense of a world of elites that is separate from the actual world perceived by citizens. The hardships of the global crisis have, thus, been followed by a surge of populism in which the contrast between "real people" and "impotent elites" is proclaimed across Europe.

This populist eruption has been fiercest in ECE. Populist resentment has run high in the region since neoliberal policies have harmed a large section of the population. Moreover, while the Union has remained obsessed with legal transformations in ECE, it has neglected the real workings of newly made formal mega-institutions. This has produced a duality based in the deep tension between the external and internal Europeanisation of ECE socio-political systems. This contrast between external and internal Europeanisation runs through the entire history of ECE political systems. Moreover, external Europeanisation has only scratched the surface of the changes required in ECE countries. Sustainable democracies are, thus, yet to emerge in the ECE region since meaningful political participation remains missing. ECE populations have perceived this gap as a high treason of the elites, with the lack of Europeanisation and democratisation in the real world pushing people into the arms of populists.

It is worth returning here to the Copenhagen criteria for EU member states, which set out general requirements about democracy and competitiveness. These criteria vaguely indicated the need for capacity for membership, but did nothing to design and implement tools to support Europeanisation and democratisation during the catch-up process. In fact, the EU "impos[ed] uniform policies and institutions on dramatically different economies and societies" since "the EU never had positive development programs for the integration of the CEE countries" (Bruszt - Langbein 2017: 1, 3). As a result, classic, democracy-supporting informal institutions were not completed in the first decades of democratisation and to date they have been beset by fatal weaknesses. It is no wonder, then, that in the 2010s, the theme "Copenhagen revisited" has returned with such a vengeance. Back in the early 2010s, critics noted the weaknesses of the Copenhagen criteria, pointing to the lack of any consistent approach to accession, assessment and assistance and fuzzy boundaries around concepts such as democracy and the rule of law. Even so, it was presumed that EU accession would unleash magical transformations in the legal-political, economic and social-cultural realms with the trickling down of formal achievements in all three areas. To attain formal membership, ECE countries had established all EU formal institutions but they did not develop proper informal civil society institutions. The assumptions were that these large formal institutions would accomplish the transition to democracy and that ECE countries that had become democratic would stay democratic. In contrast, in identifying the Copenhagen dilemma, Viviane Reding, the Commissioner for Legal Affairs, noted that the 
EU had had serious leverage to push for democratic order before accession, but it had lost the legal and other means to do so after accession. This dilemma has since taken on broader meaning, coming to refer to the paradoxical process of supporting non-democratic regimes through EU transfers.

On the basis, in the first post-accession period up to the late 2000s, an external Europeanisation programme was dominant in ECE states. These states tried to follow all the legal rules but did not change their socio-cultural environment through any kind of internal or domestic Europeanisation. Instead, they observed the EU "formalities", including those around institution-building, and created big formal institutions that produced an empty or façade democracy along with various kinds of soft "domestic" populism. Against this, the second phase of post-accession has been marked by the global crisis and subsequent hard populist and (semi-)authoritarian systems that have clearly violated the formalities of the rule of law; these systems have defied EU rules and values as part of their "alienation" from the EU mainstream. We may, thus, note a sharp contrast between the two periods: while the first was characterised by governments and parties that continued to follow EU formalities around the rule of law, in the second, incoming governments and parties have tried to circumvent EU rules and values and sometimes openly violated EU rules. These entities have cared only about the semblance, that is, the external surface representing what their domestic political system looks like from outside. They have, thus, pretended to be democratic in order to hide the undemocratic substance of their regimes. While the Polish and Hungarian regimes are classic cases of this phenomenon, other ECE countries have reflected a similar trend, at least in part. ${ }^{6}$

Finally, we may note signs of a relative or partial de-Europeanisation occurring on the EU's southern and eastern peripheries in the wake of the global crisis. Relative de-Europeanisation entails the violation of EU rules and values in a spirit of illiberal democracy, and both it and hard populism have accelerated in the 2010s. We may call this process "relative" since it has not reached the level of "absolute" de-Europeanisation, i.e. a decision to exit the Union even in the midst of post-Brexit turmoil. The EU has concentrated its crisis management efforts on saving the "main building" of European architecture, that is, the Eurozone, while fighting to keep the Schengen area intact during the refugee crisis. It is still an open question whether the relative disintegration on the southern periphery can be stopped and reversed. Meanwhile the process is certainly intensifying on the eastern periphery with deconsolidation in many sites across the ECE. Moreover, given ECE's lack of resilience to the global

6 A key example is the meeting of the Visegrád Four (V4) prime ministers with Israeli PM Netanyahu on 19 July 2017 in Budapest. This was a big show event and clear evidence of the spirit that some have called a "Europe of nations". 
crisis, it would appear that the critical turning point for relative disintegration occurred earlier in this region than it did elsewhere in the EU; in general, it seems to have happened in ECE before the crisis since these states were unable to switch to an "innovation driven economy" (see WEF 2017a, b).

The coming of an apparent age of uncertainty in the 2010s prompted a loss of historical perspective in ECE with earlier visions of the future fading for an entire population. Indeed, since the mid-2000s, the old "modernisation and Europeanisation" narrative has disappeared and a new "traditionalisation and national sovereignty" narrative has claimed the upper hand. This new narrative has eroded faith in earlier democratic structures and, with the rise of new "critical" parties, it has led to supposedly critical elections. Former mainstream parties, which represented the old pro-EU narrative and campaigned in this spirit, have since been ousted or marginalised in these elections, while parties which advocate the new "nativist" narrative have taken their place.

This effect can be explained in terms of a lack of democratic resilience, a quality that depends on state and societal resistance to crisis. In fact, a recent EU security document names the attainment of the "resilience of democracy" as a "strategic priority" for the EU, arguing that "[s] tates are resilient when societies feel they are becoming better off and have hope for the future" This is clearly not the case for ECE, which has also been missing the precondition for democratic resilience: "[s]ocietal resistance" that has been "strengthened by deepening relations with civil society, notably in its efforts to hold governments accountable" (EU Global Strategy 2016: 26-27). ECE societies have lost their vision for the future, which was based on the "modernisation and Europeanisation" narrative. In short, after the global crisis, ideas of a cohesive Europe or social Europe have either disappeared off the horizon of EU development or been reduced to pure rhetoric. The so-called social dimension of the EU and associated vision of prosperity have, thus, been lost for ECE populations. In the last quarter of a century, the internal cohesion of ECE countries has seriously decreased alongside rising inequality. Thus, we find that instead of economic cohesion, dual economies have emerged; instead of social cohesion, there has been growing social polarisation; and instead of territorial cohesion, ECE countries have been split into two - developed and underdeveloped - parts. As a result, since the early 2010s, ECE populations have lost trust in political institutions and the political class. ${ }^{7}$

7 I outline the "soft" side of relative de-Europeanisation and de-Democratisation in a parallel publication: see "The declining systemic trust in the NMS political elites: The divergence between East-Central Europe and the Baltic States", forthcoming in the Baltic Journal of Political Science. 


\section{The heavy price paid for avoiding conflicts with hard populism in the EU}

As we have seen, during the first phase of EU membership, ECE states kept up the "formalities". As a result, institution-building went ahead for large formal institutions, and this resulted in the undermining of democracy and the emergence of façade democracies. In the second phase, in contrast, declining democracies have pursued a policy of non-compliance, sometimes even openly confronting the EU. These states have defied the European architecture, clearly violating EU rules and values and engaging in a long fight with the EU over the rule of law. While Poland and Hungary were the first countries to enter into this new phase, other ECE countries have now come close though with much hesitation and some strategic moves here and there. For this reason, the standard theory of varied integration - requiring the constant stretching of that concept over several decades - cannot be extended. In its place, we need a new conceptual framework that focuses on the distinction between permissive formal Europeanisation and conflictual partial de-Europeanisation. I began this article with an analysis of the substance of de-Europeanisation in ECE, focusing on ECE's drifting away from mainstream EU socio-economic and politico-cultural developments. We need now, however, to consider the formal side of this process, that is, the violations of EU legal rules and fundamental values that are the endgame for hard populism.

In fact, since the early '90s, Viktor Orbán's governments have been developing and implementing a three-step master plan for a complete populist takeover. On coming to power in 2010, the Orbán government, thus, abandoned the historical plan of building democratic institutions, implementing EU rules and formally complying with European law. Instead, after a period of chaotic democracy and shallow EU integration, the government demonstrated its disrespect for the rule of law and maintained only a democratic façade. While formally accepting EU regulations, Orbán's government did something else, sometimes the opposite of the law, or what Orbán publicly called the "peacock dance in the EU". The new populist regime, thus, set out and systematically followed a three-stage master plan to transform Hungary from a weak democracy into a stable autocratic regime, reducing the democratic structure to a mere electoral democracy in which its re-election would be secured by means from constitutional devices to the soft power of mediatised politics. After replacing the Constitution with a fundamental law in the spirit of 19th century nationalism, the government, thus, applied its plan from the top to the bottom of the state's institutional architecture. The first step was the full capture of all state machinery from the secret services to the public media and the staffing of all top state administration positions with political appointees. The second step was the dismantling of checks-and-balances institutions with pressure on judges 
and control gained over intermediary institutions to ensure they represented government interests. And the third and final step was the de-politicisation of society through attacks on civil society to destroy all forms of civic autonomy and through a "Putinisation" branding all those with international connections as "foreign agents". 8

This periodisation suggests discrete stages of de-Europeanisation and de-democratisation in Hungary but the reality is that these steps have largely overlapped. At the same time, they have been applied systematically with a sharp and strategic focus on each stage. Under the Orbán government, Hungary has undergone almost all three stages of the master plan to demolish liberal democracy. The government is now in the third stage of attacking civil society organisations. On 4 April 2017, Hungarian parliament, thus, adopted Act XXV of 2017 on Higher Education, which targeted Central European University (usually known as "Lex CEU") with the goal of shutting the university down. On 14 June 2017, it then enacted Act LXXVI of 2017, which amended the 2011 Act on Civil Society and reduced the space for independent civic organisations with international connections, described as "Lex foreign agents".

From the inside, this process has looked like a full de-politicisation of domestic politics under the tyranny of a parliamentary majority. In contrast, it has appeared from the outside - that is, from elsewhere in the EU - as a re-nationalisation of politics, an idea symbolised by the forest of national flags that appears at public events and state press conferences where there is no EU flag in sight. At the domestic level, the Hungarian government has been doing all it can to stay in power while the darkening mood across the country has left the public apathetic. Meanwhile, at the transnational level, the government has been invoking national sovereignty as sacrosanct and pushing the EU to the absolute limit in an effort to provoke a confrontation; it has tested the Union's responses over and over. The entire process has, thus, gone beyond state capture and reached the level of a full capture of democracy. In sum, authoritarian drift has joined forces with the re-nationalisation of ECE politics. A strikingly similar picture has emerged in Poland, whose history of shallow rather than deep integration has also facilitated the brutal transformation of democratic architecture after the claiming of power. The key difference is that in Hungary, the Orbán government has enjoyed a two-thirds supermajority for most of the time since the 2010 elections while in Poland, the "good change" of de-Europeanisation and de-democratisation has only been under way since the 2015 election. The Polish government, in contrast, has had only a simple

8 This article can only provide an overview of this historical trajectory with some reference to the latest developments. On current Hungarian issues, see Bárd (2017). There is no space here to describe the Polish developments, which I have discussed elsewhere. 
parliamentary majority, which has significantly complicated its violation of EU rules and values (Bugaric - Ginsburg 2016).

These problems with the eastern periphery have come as a big surprise to the EU where "such a challenge to democratic rule was never seriously considered as something the EU may face" (Ekiert 2017: 10). As we have seen, the Orbán government attracted particular attention and special treatment when it came to power in the 2010s and began to drift seriously away from the EU mainstream, but the signs of a populist-nativist turn have also been felt in other ECE countries. Szalai-Krausz (2014) notes that in the 2010s "[t]he EU witnessing these systemic problems of rule of law, human rights and democracy has realised that the present tools at its service are limited [...] [and] not sufficient to tackle such issues" (p. 1). In fact, despite awareness of the Copenhagen dilemma, the Union has up to very recently proven defenceless against aggressive hard populist regimes. The EU's weak and controversial responses have instead had the counterproductive effect that I have termed the Juncker paradox, with the West's neglect and narrow focus on its own priorities only increasing Eastern populism. I would suggest that there have been three turning points in this process: the first was the Tavares Report (EP 2013) and the Barroso Commission's "Communication" (EC 2014) response to key divergences; the second was the 2017 European People's Party declaration, which expressed European centre-right parties' criticisms in the context of aligned parties; and the third was a September 2017 speech by Jean-Claude Juncker which has finally signalled the start of a major offensive against hard populism.

Hungary's basic divergence from the democratic mainstream under the Orbán government was described back in the Tavares Report, which was adopted by European Parliament (EP) on 3 July 2013 with the support of a large majority. This report is still the most precise EU document on the decline of democracy in ECE. In discussing the Hungarian case, it called for a "Copenhagen Commission" with an all-European scope and stressed the need for the "establishment of a new mechanism to ensure compliance by all Member States with the common values enshrined in Article 2 TEU" (Tavares 2013: 15). Known as the guardian of democracy, EP has remained the most active institutional defender of democracy based on the rule of law in the EU; it, thus, initiated a series of parliamentary debates on the "situation in Hungary" that reflected this critical mood (see e.g. EP 2015,2016,2017c, b). At the same time, the Tavares Report also exposed EP to a wider public debate, leading to calls for the oversight of the rule of law, democracy and fundamental rights in all member states.

Though the Barrosso Commission (2009-2014) operated in the toughest period of global crisis management as hard populist and/or Eupopulist regimes emerged in ECE, it developed some sensitivity to the ECE situation, responding first to a series of violations of the rule of law. The initial turning point was President Barroso's Union address (State of the Union, 12 September 
2012), which introduced the term "systemic failure" in an early reference to the Hungarian situation. By 2013, all three major EU institutions had entered the debate in diverging roles. The Commission, the so-called guardian of treaties, soon became the chief actor, delivering an important decision in 2014. That basic document, known as the Commission Communication of 11 March 2014, marked a legal innovation, presenting new holistic concepts like "systemic failure" and "systemic threats" to the rule of law and offering a "framework" to counter the problem:

Today the European Commission adopted a new framework for addressing systemic threats to the rule of law in any of the EU's 28 Member States. [...] $[\mathrm{T}]$ here is a need to develop a tool to deal at the EU level with systemic threats to the rule of law. [...] The new framework does not constitute or claim new competences for the Commission but makes transparent how the Commission exercises its role under the Treaties. [...] The framework can be activated in situations where there is a systemic breakdown which adversely affects the integrity, stability and proper functioning of the institutions and mechanisms established at national level to secure the rule of law. The EU framework is not designed to deal with individual situations of isolated cases of breaches of fundamental rights or miscarriages of justice. (EC 2014: 1, 2)

This March 2014 Commission Communication achieved a breakthrough with its new framework that might be summed up by the key words "systemic" and "master plan". Under the Commission's holistic approach, posing a systemic threat to Europeanisation was seen as a serious violation of EU rules and values; moreover, the systemic action of hard populism was countered with the same strategy on the EU's side. The Commission argued that Article 2 of the Treaty on the European Union (TEU) did not, in fact, simply present a list of discrete values and the related requirements for proper behaviour by member states; rather, this was a comprehensive and coherent system of values defining the European democratic system in its entirety. All in all, this Commission Communication cleared the way to tackle serious and systemic violations of the rule of law framework (RoLF). For all its shortcomings, this was an innovative document and it made for a good start to 2014 even if in some ways it was too little too late. Notably, it remained both too much and too soon for the Council, which sabotaged its implementation for years in actions led by the UK and joined by ECE governments.

Undoubtedly, there were two big problems with the EU's new "master plan". First of all, there was a presumption that "suspected" member states were ready and willing to engage in dialogue, and, thus, that this "mechanism" was bound to produce a positive result. This presumption was highly questionable since in countries where the ruling elites had made a conscious choice to flout EU rules, engaging in such a dialogue was unlikely to be fruitful. Secondly, the Council's legal service claimed that the Commission had overstepped its powers 
and that the new regulation undermined the role of member states within the Council. Unsurprisingly, this criticism of RoLF originated from governments with poor records on the rule of law. Ultimately, then, as Kochenov and Pech (2015) conclude, while the RoLF was designed to address systemic threats to EU rules under Article 2 of the TEU, it continued to represent the "triumph of empty rhetoric over genuine action" (p. 3). ${ }^{9}$

In any case, the innovative first step taken by the Barroso Commission was halted with the arrival of a new Commission. From the very outset, the new Juncker Commission was overwhelmed by the "polycrisis" and focused on crisis management in the Core by marginalising all other issues including the deepening Core-Periphery divide noted in the RoLF. Russack (2017) has analysed the Juncker Commission's ten priorities in 2014, recalling its motto, "Be big and more ambitious on big things and small and more modest on small things" (p. 2). This strategy obviously misfired when it came to the "small things" since the violations of EU rules and values actually turned into a frozen conflict. Moreover, the marginalising of the new crisis in the "East" through permanent conflict avoidance only made the situation much worse. As late as the mid-2010s, the Juncker Commission did not realise that ECE countries had been seriously hit by the global crisis or that this had unleashed a vicious circle of violations of Article 2 of the TEU. Nevertheless, by this point it was obvious that ECE's deep structural problems originated from the lack of any special catch-up programme in the Copenhagen criteria, the accession process or any part of formal-legal "judicial integration". ECE's serious socio-economic problems had erupted after the global crisis, and the profound controversies around the region had come to the surface in the violations of EU legal formalities.

Since 2014 when the Commission declared itself too busy with "home affairs" in the Core, European Parliament has replaced it as the chief player in the RoLF, reflecting the Commission's very earliest involvement in this process in cooperation with European Parliament. Several events have demonstrated the fallacy of the Commission's assumptions about starting a "dialogue" with the Orbán government. That government has been systematically demolishing liberal democracy in Hungary and remains unready to engage in any dialogue. Instead, it has continued to enact its own master plan while making a few partial and specific compromises on infringement procedure issues. In contrast, under public pressure in the West, EP has dealt more efficiently with the Orbán government. EP resolutions on the "situation in Hungary" have detailed a long

9 There is extensive scientific literature about the RoLF. See, e.g., Closa and Kochenov (eds) (2016), Bárd et al. (2017) and Kaltwasser et al. (2017) and, beyond this, a plethora of professional blogs including Akkerman (2017), Blokker (2017), Brunnbauer and Haslinger (2017), Easterly (2016), Judis (2016), Juhász and Szicherle (2016), Katsambekis (2016), Katsambekis and Stavrakakis (2016), LSP blogs-five views (2017), Szczerbiak (2017) and Youngs (2016). 
list of the Hungarian government's conflicts with EU laws and authorities and provoked wide discussion.

These EP resolutions have not, however, significantly changed the activities of the Commission, which remains "in dialogue" about separate infringement procedures over ongoing violations by the Orbán government since the first half of 2017. As usual, these conflicts have been marginalised by EU authorities, which are irritated by Orbán's behaviour but consider it unimportant amidst the complexities of the EU polycrisis. So far, the Commission has also taken a "light-touch" approach to the infringement procedures around Hungary's new regulations. Meanwhile, what the EU assumed was just "window dressing" through "judicial integration" has started to look more like a broken window scenario in Hungary. During an EP plenary session about Lex CEU, MEPs pointed out that the EU was passively witnessing the systemic erosion of democracy in Hungary and they called for tougher measures. In response, on 26 April 2017, the Commission's Frans Timmermans informed EP that the Commission had launched an infringement procedure against the Hungarian government over this new "Higher Education Act". Again, however, this has led nowhere.

At the same time, the Orbán government-EU conflict has only deepened over the refugee crisis and the "Stop Brussels" campaign. In this context, a second turning point can be seen in a statement by EPP - part of the same group as Orbán's Fidesz - which expressed its profound disturbance at Orbán's extremism and took the strongest stance yet on the situation:

The EPP Presidency sent a clear message to Prime Minister Orbán and his party, Fidesz that we will not accept that any basic freedoms are restricted or rule of law disregarded. [...] The EPP has also made it clear to our Hungarian partners that the blatant anti-EU rhetoric of the "Let's stop Brussels" consultation is unacceptable. The constant attacks on Europe, which Fidesz has launched for years, have reached a level we cannot tolerate. (EPP 2017: 2).

It is clearly this message that led to the historic EP resolution calling for the application of Article 7 of the TEU against Hungary. This resolution was adopted by a large majority on 17 May 2017. Additionally, on 6 September 2017, the European Court of Justice rejected a claim by Hungary - together with Slovakia and supported by Poland - which challenged the allocation of refugees to those member states. This growing list of conflicts and confrontations awaits a serious response from the EU.

\section{Conclusion: "Taming the beast" - Confronting hard populism in the EU}

In responding to the widening Core-Periphery divide, the Core's prevailing mindset has been one of preoccupation with its own "priorities", which has actually meant reducing complex management tasks to direct and urgent conflict 
management. This has led, in turn, to conflict avoidance and inaction in the Periphery. At the same time, the entire Eastern periphery has been undergoing an intensifying desecuritisation-deconsolidation process as these member states experience the drastic weakening of their positions both in the Union and in terms of global competitiveness. In general, the violations of liberal democracy by both Hungary and Poland in the 2010s have demonstrated that the rule of law now is now a contested concept. Originally this concept was developed for nation states to prevent any conflicts around "national sovereignty". In the EU, however, it has been upgraded with an international-transnational dimension, incorporating multiple players from the international context including the $\mathrm{Eu}$ ropean Court of Justice, the European Court of Human Rights and the Council of Europe with its influential Venice Commission. This situation presents a conflict by design since no proper law enforcement mechanism has been created for the "borderlines". As a result, the domestic debate has been sabotaged by the Hungarian and Polish governments with their constant references to "national sovereignty". The conflict has only escalated with the rise of the Kaczynski regime in Poland and the further decline of democratic structures in the other ECE states under unstable coalition governments.

At the same time, given the particular historical legacy of ECE states, their late arrival in the EU and their internal debates, they have often been reluctant to present their situations and legitimate regional interests to the EU. Despite the ugly face of current hard populist regimes, the message of the Visegrád Four (V4) to the March 2017 EU Rome Summit has particular relevance: "Member States' identities and diverse traditions represent a key asset of the EU and shall remain a reference for its further developments" (V4 Joint Statement 2017: 3). In fact, Central European populations from Vienna to Prague, Bratislava to Budapest and Warsaw to Ljubljana have different historical experiences of non-European migration than their West European counterparts (Eupinions 2016; Pew 2016). Their social and cultural unpreparedness for the influx of refugees can easily be manipulated by xenophobic autocratic regimes in "Stop Brussels" campaigns under the pretext of protecting national sovereignty and culture.

Undoubtedly, the EU's behaviour in the recent geopolitical crisis has assumed the EU's total cultural homogeneity including on migration matters while also completely neglecting historically hidden and emerging issues in Central Europe as a whole (i.e. the V4 + Austria and Slovenia). Of the ten Juncker priorities presented on the installation of the new Commission, even those coming closest to sensitive rule-of-law and refugee-crisis issues - Priority 7 and Priority 8 - make no reference to ECE attitudes to the refugee crisis or rule-of-law violations in ECE states or the need for conflict management is these areas (EP 2017a: 20-26). This is an example of structural neglect and repeated inaction in crisis management. Notwithstanding the great and real significance of all ten 
priorities, the complex silence around these specific problems in ECE amounts to a crisis of crisis management in the so-called East. ${ }^{10}$

There can be no question that the beast of ECE hard populism has to be tamed. After all, as Ekiert (2017) observes of Poland and Hungary:

[b]oth governments introduced politically motivated legislation that constituted clear breaches of EU law and European values, undermined the rule of law, and restricted individual freedoms. What we see in these two countries is a determined effort to really subvert the existing democratic system in a fundamental way (p. 7).

After a long series of declarations by Western leaders, Jean Asselsborn, Luxembourg's Minister of Foreign Affairs has recently stated with some justification that these brutal violations of EU values call into question these states' EU membership: "[By] the end of this year after all important elections are concluded, we need to ask Poland and Hungary whether they want to stay within the European Union and observe its principles" (quoted in Ekiert 2017: 3 ). Indeed, the Juncker paradox of tolerating hard populism through neglect has been pushed to its limits. As Mudde (2017) noted recently: "The EU has tolerated Viktor Orbán too long. It has to take a stand now" (p. 1).

The end of 2017 has seen a new turning point on these issues. The EU has experienced consolidation after the global crisis while Brexit now appears to be manageable on the Union's side. At the same time, key state elections have been won by stopping the populist wave, and the discontent of developed EU states with ECE hard populism has reached a critical mass. Western leaders have sent the repeat message that enough is enough and there can no more patience around rule-of-law violations by Polish and Hungarian hard populist regimes. In a somewhat optimistic mood, the EU has begun to propose stronger and wider forms of integration. Both this optimism and the new policy against hard populism were communicated powerfully in Juncker's latest State of the Union address. Coming after the presentation of five scenarios for the EU in March 2016, the address outlined a new strategy ("scenario six") for the accelerated further federalisation of the EU including a strong warning that all member states must respect the rule of law in the EU (Juncker 2017: 4-5, 13 September 2017). ${ }^{11}$

All in all, 2017 has been a "reflection year" for the EU (Andor 2017: 1). Responding to Juncker's address, Daniel Gros (2017), thus, asks a basic question:

10 Viviane Reding, the chief architect of the RoLF, recently stated "we have to ask ourselves: what to do when a Member State knowingly destroys the constitutional basis of its democracy? That is why the institutions need new tools to credibly counter these new challenges." (2017: 2).

11 As Grabbe and Lehne (2017) report, various actors including governments have suggested that "new conditions that would tie the access to EU funds to a country's performance on governance and the rule of law" might have "a powerful deterrent effect", noting that it is "[t]ime for [g]overnments to [t] ake a [s]tand" (p. 6). 
"Where is Europe heading?" His answer directly echoes the two key messages of the address as well as the emerging public consensus in the EU. On the one hand, Brexit provides a new opportunity for greater integration, while on the other, it makes clear ECE hard populism remains a major obstacle to that same integration:

The departure of the UK now opens the door for a future in which essentially all member states share one currency and their citizens are free to move across borders without control. [...] Unfortunately, however, a new threat to Europe's future has now reared its ugly head. This time, it concerns the nations' commitment to the democratic values of the Union, notably the principle of the rule of law, the independence of the judiciary and the importance of a free press. This is a fundamental conflict (basically between the old member states, on one side, and Poland and Hungary, on the other), which cannot be papered over with financial concessions or some other compromise. Nevertheless, it must be resolved before the EU can make further progress down the road mapped out by President Juncker (Gros 2017: 1)

All public opinion polls show that the vast majority of Hungarians and Poles support EU membership and feel proud to be European citizens. The Hungarian and Polish publics have experienced EU membership for more than a decade, and thus, a new generation has grown up in the midsst of Europeanisation and democratisation. Having come through the years of societal frustration that led to the capture of their democracies by hard populist regimes, Poland and Hungary can and will return to the mainstream of European development, and they will do this with full democracy and respect for the rule of law.

\section{References}

Agerberg, Mattias (2017): Failed expectations: Quality of government and support for populist parties in Europe, European Journal of Political Research 56(3): 578-600.

Akkerman, Tjitske (2017): Populism is overrated - if there is a threat to democracy, it's from authoritarian nationalism, LSE blog, http://blogs.lse.ac.uk/europpblog/2017/07/31/populism-is-overrated-if-there-is-a-threat-to-democracy-its-from-authoritarian-nationalism/.

Antonelli, Maria Alexandra and Valeria De Bonis (2017): How do European welfare states perform? Social Europe, https://www.socialeurope.eu/2017/07/european-welfare-states-perform/.

Andor, László (2017): Cohesion and conditionality in the EU, Progressive Economy, http://www. progressiveeconomy.eu/sites/default/files/LA-cohesion-final.pdf.

Ágh, Attila (2016a): The Decline of Democracy in East-Central Europe: Hungary as the Worst-Case Scenario, Problems of Post-Communism 63 (5-6): 277-287, http://www.tandfonline.com/doi/ pdf/10.1080/10758216.2015.1113383?needAccess=true. 
Ágh, Attila (2016b): Rocky Road of Europeanization in the New Member States: From democracy capture to the second try of democratization, Polish Sociological Review (1): 71-86.

Ágh, Attila (2016c): Increasing Eupopulism as the megatrend in East-Central Europe: From façade democracies to velvet dictatorships, Baltic Journal of Political Science (5): 21-39.

Ágh, Attila (2016d): Deconsolidation of Democracy in East-Central Europe: The New World Order and the geopolitical crisis in the EU, Politics in Central Europe 12(3): 7-36.

Bárd, Petra (2017): The Open Society and Its Enemies: An attack against the CEU, academic freedom and the rule of law, CEPS, 14 April 2017, https://www.ceps.eu/system/files/PBard_ Hungary\%20and\%20CEU.pdf.

Bárd, Petra, Sergio Carrera, Elspeth Guild and Dimitry Kochenov (2016): An EU mechanism on Democracy, the Rule of Law and Fundamental Rights, CEPS, April 2016, https://www.ceps.eu/ system/files/LSE\%20No\%2091\%20EU\%20Mechanism\%20for\%20Democracy.pdf.

BF, Bertelsmann Foundation (2016): East-Central and Southeast Europe: Populists on the rise (44-53), in Transformation Index 2016, Gütersloh: Verlag Bertelsmann Stiftung, p. 130.

BF, Bertelsmann Foundation (2017): Core European Values Under Threat, Flashlight Europe, August 2017, http://www.bertelsmann-stiftung.de/fileadmin/files/BSt/Publikationen/GrauePublikationen/EZ_flashlight_europe_2017_08_ENG.pdf.

Blokker, Paul (2017): Populist Constitutionalism, Verfassungsblog, 4 May 2017, http://verfassungsblog.de/populist-constitutionalism/.

Brunnbauer, Ulf and Peter Haslinger (2017): Political mobilization in East Central Europe, Nationalities Papers, 45 (3): 337-344, http://www.tandfonline.com/doi/pdf/10.1080/00905992. 2016.1270922?needAccess=true.

Bruszt, László and Julia Langbein (2017): Varieties of dis-embedded liberalism. EU integration strategies in the Eastern peripheries of Europe, Journal of European Public Policy 24(2): 297-315.

Bruter, Michael (2008): Legitimacy, Euroscepticism and Identity in the European Union, Journal of Contemporary European Research 4(4): 273-284.

Bugaric, Bojan and Tom Ginsburg (2016): The Assault on Postcommunist Courts, Journal of Democracy 27(3): 69-82.

Buti, Marco and Karl Pichelmann (2017): European integration and populism, LUISS School of European Political Economy, Policy Brief, 30 January 2017, http://sep.luiss.it/sites/sep.luiss.it/ files/Buti_PB_01302017.pdf, available also at http://voxeu.org/article/european-integration-and-populism-addressing-dahrendorfs-quandary.

Closa, Carlos and Dmitry Kochenov (eds) (2016): Reinforcing rule of law oversight in the European Union, Cambridge University Press, p. 356.

Dawson and Hanley (2016): East Central Europe: The Fading Mirage of the 'Liberal Consensus, Journal of Democracy 27(1): 20-34.

Donovan, Todd and Jeffrey Karp (2017): “Electoral rules, corruption, inequality and evaluations of democracy", European Journal of Political Research 56(3): 469-486.

Duchesne, Sophie (2014): Smoke and Mirrors, http://en.theeuropean.eu/sophie-duchesne/7933european-identity-no-use-for-now?. 
Easterly, William (2016): Democracy Is Dying as Technocrats Watch, Foreign Policy, 23 December 2016, https://foreignpolicy.com/2016/12/23/democracy-is-dying-as-technocrats-watch/.

EC, European Commission (2014): A new EU Framework to strengthen the Rule of Law, Brussels, 11. 3. 2014, $\operatorname{COM}(2014) 158$ final.

Ehala, Martin (2017): Signs of Identity: The Autonomy of Belonging, Routledge, p. 182

Ekiert, Grzegorz (2017) How to deal with Poland and Hungary, Social Europe, https://www. socialeurope.eu/wp-content/uploads/2017/08/Occ-Pap-13-PDF.pdf.

Engesser, Sven, Nayla Fawzi and Anders Olof Larsson (2017): Populist online communication: introduction to the special issue", Information, Communication and Society 20(9): 1279-1292, http://www.tandfonline.com/doi/pdf/10.1080/1369118X.2017.1328525.

EP, European Parliament (2013): Tavares Report on the situation of human rights: standards and practices in Hungary, European Parliament, Committee on Civil Liberties, Justice and Home Affairs, 2012/2130(INI), 2. 5. 2013, http://www.europarl.europa.eu/sides/getDoc.do?pubRef=-// $\mathrm{EP} / / \mathrm{NONSGML+COMPARL+PE-508.211+02+DOC+PDF+V0//EN} \mathrm{\&} \mathrm{language=EN.}$

EP, European Parliament (2015): Situation in Hungary, resolution on 10 June 2015, https://www. biicl.org/documents/652_ep_res_on_hungary.pdf?showdocument=1.

EP, European Parliament (2016): Report with recommendations to the Commission on the establishment of an EU mechanism democracy, the rule of law and fundamental rights, 10 October 2016, http://www.europarl.europa.eu/sides/getDoc.do?pubRef=-//EP//TEXT+REPORT+A82016-0283+0+DOC+XML+V0//EN.

EP, European Parliament (2017a): The Juncker Commission's ten priorities, http://www.europarl. europa.eu/RegData/etudes/IDAN/2017/595876/EPRS_IDA(2017)595876_EN.pdf.

EP, European Parliament (2017b): Situation in Hungary (text adopted on 17 May 2017), http:// www.europarl.europa.eu/sides/getDoc.do?pubRef=-//EP//NONSGML+TA+P8-TA-20170216+0+DOC+PDF+V0//EN.

EP, European Parliament (2017c): Fundamental rights in Hungary: MEPs call for triggering Article 7, 17 May 2017 (press release), http://www.europarl.europa.eu/pdfs/news/expert/infopress/2 0170511IPR74350/20170511IPR74350_en.pdf.

EPP, European People's Party (2017): Prime Minister Orbán to comply with EU laws and EPP values following meeting with EPP Presidency, 29 April 2017, http://www.epp.eu/press-releases/ prime-minister-orban-to-comply-with-eu-laws-and-epp-values-following-meeting-with-epp-presidency/.

EU Global Strategy (2016): Shared Vision, Common Action: A Stronger Europe, A Global Strategy for the European Union's Foreign and Security Policy, 28 June 2016, http://www.eeas.europa. eu/archives/docs/top_stories/pdf/eugs_review_web.pdf.

Eupinions (2016/3): De Vries, Catherine and Isabell Hoffmann: Fear not Values: Public opinion and the populist vote in Europe, Bertelsmann, Eupinions 2016/3, p. 30, https://www.bertelsmann-stiftung.de/fileadmin/files/user_upload/EZ_eupinions_Fear_Study_2016_ENG.pdf.

FH, Freedom House (2017): Nations in Transit 2017: The False Promise of Populism, https:// freedomhouse.org/sites/default/files/NIT2017_booklet_FINAL_0.pdf. 
Fomina, Joanna and Jaczek Kucharczyk (2017): The Specter Haunting Europe: Populism and Protest in Poland Journal of Democracy 27(4): 58-68.

Grabbe, Heather and Stefan Lehne (2017): Defending EU values in Poland and Hungary, Carnegie Europe, http://carnegieeurope.eu/2017/09/04/defending-eu-values-in-poland-and-hungary-pub-72988.

Gros, Daniel (2017): Where is Europe heading? CEPS, September 2017, https://www.ceps.eu/ content/where-europe-heading.

Haughton, Tim and Kevin Deegan-Krause (2015): Hurricane Season: Systems of Instability in Central and East European Party Politics, EEPS 29(1): 61-80, https://www.researchgate.net/ publication/272377297_Hurricane_Season.

Havlik, Vlastimil and Petr Voda (2016): The Rise of New Political Parties and Re-Alignment of Party Politics in the Czech Republic, Acta Politologica, 119-144, http://acpo.vedeckecasopisy. cz/publicFiles/001209.pdf.

Judis, John (2016): Us v Them: the birth of populism, The Guardian, The long read, 13 October 2016, https://www.theguardian.com/politics/2016/oct/13/birth-of-populism-donald-trump.

Juhász, Attila and Patrik Szicherle (2017): The political effects of the migration-related fake news, disinformation and conspiracy theories in Europe, Political Capital, http://www.politicalcapital.hu/pc-admin/source/documents/FES_PC_FakeNewsMigrationStudy_EN_20170607.pdf.

Juncker, Jean-Claude (2017): State of the Union Address 2017, http://europa.eu/rapid/press-release_SPEECH-17-3165_en.htm.

Kaltwasser, Cristobal Rovira, Paul Taggart, Paulina Ochoa Espajo and Pierre Ostiguy (eds) (2017): The Oxford Handbook of Populism, p. 736.

Katsambekis, Giorgios (2016): The Populist Surge in Post-Democratic Times: Theoretical and Political Challenges, The Political Quarterly, 16 December 2016 (online version).

Katsambekis, Giorgios and Yannis Stavrakakis (2016): European social scientists should seek to critically engage with populism rather than simply attacking or idealising it, http://blogs.lse. ac.uk/europpblog/2013/08/23/european-social-scientists-should-seek-to-critically-engage-with-populism-rather-than-simply-attacking-or-idealising-it/.

Klipcerova-Baker, Martina and Jaroslav Kostál (2017): Post-communist democracy vs. totalitarianism: Contrasting patterns of need satisfaction and societal frustration, Communist and Post-Communist Studies 50: 99-111

Krastev, Ivan (2016): What's wrong with East-Central Europe? Liberalism's Failure to Deliver, Journal of Democracy 27(1): 35-39.

Lehne, Stefan (2016): The Tempting Trap of Fortress Europe, 21 April 2016, Carnegie Europe, http://carnegieeurope.eu/2016/04/21/tempting-trap-of-fortress-europe/ixdx.

LSE blogs (2017): Five views: Is populism a threat to democracy? http://blogs.lse.ac.uk/europpblog/2017/07/24/is-populism-really-a-threat-to-democracy/.

Merler, Silvia (2017a): European identity and the economic crisis, Bruegel, 5 March 2017, http:// bruegel.org/2017/03/european-identity-and-the-economic-crisis/. 
Merler, Silvia (2017b): Rebuilding economic and political capital for EU integration, Policy network, 31 March 2016, http://www.policy-network.net/pno_detail.aspx?ID=5082 \& title=Rebuilding+economic+and+political+capital+for+EU+integration.

Moffitt, Benjamin (2016): The Global Rise of Populism: Performance, Political Style and Representation, Stanford University Press, p. 240.

Mudde, Cas (2017): The EU has tolerated Orbán for too long, Guardian, 3 April 2017, https:// www.theguardian.com/commentisfree/2017/apr/03/eu-tolerated-viktor-orban-hungarian-central-european-university.

Pew (2016): Europeans Fear Wave of Refugees Will Mean More Terrorism, Fewer Jobs, 11 July 2016, http://www.pewglobal.org/2016/07/11/europeans-fear-wave-of-refugees-will-mean-more-terrorism-fewer-jobs/.

Rupnik, Jacques (2016): The Specter Haunting Europe: Surging illiberalism in the East", Journal of Democracy 27(4): 77-87.

Russack, Sophia (2017): How is Juncker's 'last chance Commission' faring at mid-term? Swedish Institute for European Policy Studies, June 2017, https://www.ceps.eu/system/files/SR_JunckerCommission_0.pdf.

Scharpf, Fritz (2015): After the Crash: A perspective on Multilevel European Democracy", European Law Journal 21(3): 384-403.

Szalai-Krausz, Vivien (2014): The Rule of Law Framework of the European Union, https://www. iei.liu.se/stat/utbildning-grundniva/uppsatser/juni-2014-master/1.569130/MasterThesis-V. Szalai-Krausz-LiU-MIER.pdf.

Szczerbiak, Alex (2017): How is the European migration crisis affecting Polish politics?, Social Europe, 14 July 2017, https://www.socialeurope.eu/2017/07/49234/.

V4 Joint Statement (2017): Input to Rome Declaration 2017, 2 March 2017, https://www.premier. gov.pl/files/files/joint_statement_of_the_heads_of_governments_of_the_v4_countries_0. pdf.

WEF, World Economic Forum (2017a): The inclusive growth and development report 2017, https:// www.weforum.org/reports/the-inclusive-growth-and-development-report-2017.

WEF, World Economic Forum (2017b): The Global Human Capital Report, http://www3.weforum. org/docs/WEF_Global_Human_Capital_Report_2017.pdf.

WEF, World Economic Forum (2017c): The Global Competitiveness Report 2017-2018, 26 September 2017, https://www.weforum.org/reports/the-global-competitiveness-report-2017-2018.

Youngs, Richard (2016): How we can reframe the debate about Europe's populist threat, http:// blogs.lse.ac.uk/europpblog/2016/11/17/how-we-can-reframe-the-debate-about-europes-populist-threat/.

Attila Ágh is a Professor in the Political Science Department at the Budapest Corvinus University. He was the founder and the former Head of Department of Political Science at this University, the Director of the Research Centre "Together for Europe" 
and also the President of the Central European Political Science Association (CEPSA). He was a visiting professor at many universities from Aarhus to Vienna, and also from New Delhi to Los Angeles. His major research interest is comparative politics with special regard to the EU developments, focusing the Europeanization and Democratization in the New Member States. He has published more than twenty books and dozens of papers in the international journals.Email: attila.agh@chello.hu. 